Research, Society and Development, v. 9, n. 10, e9439109328, 2020

(CC BY 4.0) | ISSN 2525-3409 | DOI: http://dx.doi.org/10.33448/rsd-v9i10.9328

\title{
Quail growth curve model identity
}

Identidade de modelos de curva de crescimento de codornas

Identidad de los modelos de curvas de crecimiento de codornices

Received: 10/15/2020 | Reviewed: 10/22/2020 | Accept: 10/26/2020 | Published: 10/28/2020

Marta Jeidjane Borges Ribeiro

ORCID: https://orcid.org/0000-0002-8459-1981

Universidade Federal de Sergipe, Brasil

E-mail: emestatistica@gmail.com

Fabyano Fonseca e Silva

ORCID: https://orcid.org/0000-0001-9536-1113

Universidade Federal de Viçosa, Brasil

E-mail: fabyanofonseca@ufv.br

Claudson Oliveira Brito

ORCID: https://orcid.org/0000-0002-3339-8647

Universidade Federal de Sergipe, Brasil

E-mail: claudson@ufs.br

Ana Paula Del Vesco

ORCID: https://orcid.org/0000-0002-0145-7817

Universidade Federal de Sergipe, Brasil

E-mail: apaulavesco@gmail.com

Maíse Santos Macário

ORCID: https://orcid.org/0000-0002-8841-5184

Universidade Federal de Sergipe, Brasil

E-mail: maisemacario@yahoo.com.br

Camilla Mendonça Silva

ORCID: https://orcid.org/0000-0001-5259-9316

Universidade Federal de Sergipe, Brasil

E-mail: camillamsazoo@gmail.com

Leandro Teixeira Barbosa*

ORCID: https://orcid.org/0000-0002-1580-8913

Universidade Federal de Sergipe, Brasil

E-mail: leandro@ufs.br 


\begin{abstract}
In this study, we sought to apply the model identity technique to compare the influence of eight treatments on growth parameters for three broiler quail lines, estimated using a logistic nonlinear regression model. For the analysis, we used the weight and age data obtained for three lines of European broiler quails (Coturnix coturnix coturnix) in a completely randomized $2 \times 4$ factorial scheme, with two levels of metabolizable energy (2900 and $3100 \mathrm{kcal}$ of ME $\mathrm{kg}^{-1}$ of diet), four levels of raw protein $(22 \%, 24 \%, 26 \%$ and $28 \%$ crude protein), and six repetitions. Results obtained for model identity tests indicated that although there were no significant differences among the parameters of the model between the treatments evaluated in each strain, there were, with the exception of Treatment 5 (3100 kcal of $\mathrm{ME} \mathrm{kg}^{-1}$ and $22 \%$ crude protein), significant differences with respect to the adult weight parameter between lines within each treatment.
\end{abstract}

Keywords: Coturnix coturnix coturnix; Logistic model; Nonlinear model; Equality of parameters; Likelihood ratio.

\title{
Resumo
}

Objetivou-se aplicar a técnica de identidade de modelos para comparar a influência de oito tratamentos e três linhagens de codorna de corte, sobre os parâmetros estimados pelo modelo de regressão não linear logístico. Para a análise foram utilizados dados de peso e idade, de codornas européias de corte (Coturnix coturnix sp.) provenientes de três linhagens, em um esquema fatorial $2 \times 4$, instalado em um delineamento inteiramente casualizado, com dois níveis de energia metabolizável (2900 e $3100 \mathrm{kcal}$ de EM/kg de dieta), e quatro níveis de proteína bruta $(22 \%, 24 \%, 26 \%$ e $28 \%$ de proteína bruta), com seis repetições. Realizou-se o teste de identidade de modelos e constatou-se que não houve diferenças significativas para os parâmetros do modelo entre os tratamentos avaliados em cada linhagem, contudo, houve diferença significativa, exceto para o Tratamento 5, do parâmetro peso adulto entre linhagens dentro de cada tratamento.

Palavras-chave: Coturnix coturnix coturnix; Modelo logístico; Modelo não linear; Igualdade de parâmetros; Razão de verossimilhança.

\section{Resumen}

El objetivo fue aplicar la técnica de identidad del modelo para comparar la influencia de ocho tratamientos y tres líneas de corte de codorniz, sobre los parámetros estimados por el modelo de regresión logística no lineal. Para el análisis se utilizaron datos de peso y edad, de codorniz 
europea (Coturnix coturnix sp.) De tres líneas, en un esquema factorial 2x4, instaladas en un diseño completamente aleatorizado, con dos niveles de energía metabolizable (2900 y 3100 $\mathrm{kcal}$ de EM/kg de alimento), y cuatro niveles de proteína cruda (22\%, 24\%, $26 \%$ y $28 \%$ de proteína cruda), con seis repeticiones. Se realizó la prueba de identidad del modelo y se encontró que no hubo diferencias significativas para los parámetros del modelo entre los tratamientos evaluados en cada cepa, sin embargo, sí hubo una diferencia significativa, excepto para el Tratamiento 5, del parámetro de peso adulto entre cepas dentro de cada tratamiento.

Palabras clave: Coturnix c. coturnix; Modelo logístico; Modelo no lineal; Igualdad de parámetros; La razón de verosimilitud.

\section{Introduction}

Quail production at the national level has grown in recent years, mainly due to the lower costs of poultry production, and the inherent characteristics of bird physiology, as quails are precocious birds that have a high growth rate (Karadavut et al., 2017). However, despite the intense interest, there is little information available regarding the characteristic's growth curves of European quails (Couturnix couturnix sp.) from the perspective of meat production. Such information can provide researchers with strategic knowledge that can be used to establish more efficient nutritional management and facilitate the design of dedicated selection programs for different strain (Santos et al., 2012).

Among the diverse applications of growth curves in animal production, the following are of particular importance: summarization, in three or four parameters, of the characteristics of population growth, given that some parameters of the nonlinear models have biological interpretation; evaluation of the treatment response profile over time; and the study of interactions of the responses of subpopulations or treatments with time and to identify the heaviest and the youngest animals within a specific population (Brusamarelo et al., 2020).

The growth characteristics of animals have a direct influence the quantity and quality of the meat produced. Thus, studies related to growth curves have strategic application in genetic improvement programs, contribute to the definition of selection criteria regarding the finishing precocity and speed of weight gain, and can facilitate the development of more efficient production systems for different breeds and regions with respect to the management of animals, feeding programs, and determination of breeding or lines (Souza et al., 2010; Silva et al., 2011). In this regard, Arango and Van Vleck (2002) stressed that it is necessary to consider growth 
(CC BY 4.0) | ISSN 2525-3409 | DOI: http://dx.doi.org/10.33448/rsd-v9i10.9328

and maturity characteristics derived from the study of growth curves as additional information in genetic improvement programs.

In addition to facilitating verification of differences in the growth of different lines used in the production of animal protein, growth curve determinations make it possible to identify the ideal time to change diets, based on a knowledge of the parameters of nonlinear models (Grieser et al., 2015). According to Santos et al. (2018), lines that reach adult weight at an earlier age have a higher nutritional demand than slower growing lines.

Thus, to enable a better description of the growth curve of birds, it is necessary to identify mathematical models that provide the best fits, and also to determine the parameters of the equations that facilitate characterization of the growth patterns of evaluated animals. In this regard, Silveira et al. (2011) have suggested that in addition to selection of the best model, when considering multiple populations, researchers are also interested in comparing curve parameters to identify those populations in which the growth process is most efficient, and for this purpose, Regazzi (2003) has proposed that use of the model identity technique is the most suitable approach.

In this study, we accordingly used the model identity technique, with the objective of evaluating the influence of different treatments on the estimated parameters used to describe the growth curve of different lines of European broiler quails.

\section{Methodology}

The experiment was carried out in the city of São Cristóvão/Sergipe, Brazil (11º 00 '53 "S and $\left.37^{\circ} 12^{\prime} 23^{\prime \prime} \mathrm{W}\right)$.

In this study, we evaluated a total of 576 seven-day-old male and female chicks of three different lines of European broiler quails (Coturnix coturnix sp.). The birds were distributed in an entirely randomized experimental design, with six repetitions composed of 12 quails per experimental unit in a $2 \times 4$ factorial scheme, two metabolizable energy levels of 2900 and 3100 kcal of ME $\mathrm{kg}^{-1}$ diet and four levels of raw protein $(22 \%, 24 \%, 26 \%$, and $28 \% \mathrm{CP}$ ), with treatments representing different combinations of the different factor levels (Table 1). The quails were weighed at 7-day intervals until reaching 42 days of age. 
Table 1 - Experimental treatments.

\begin{tabular}{ccc}
\hline Metabolizable Energy Level (kcal) & Crude Protein (\%) & Treatments \\
\hline \multirow{2}{*}{2900} & 22 & $\mathrm{~T} 1$ \\
& 24 & $\mathrm{~T} 2$ \\
& 26 & $\mathrm{~T} 3$ \\
& 28 & $\mathrm{~T} 4$ \\
\multirow{2}{*}{3100} & 22 & $\mathrm{~T} 5$ \\
& 24 & $\mathrm{~T} 6$ \\
& 26 & $\mathrm{~T} 7$ \\
& 28 & $\mathrm{~T} 8$ \\
\hline
\end{tabular}

Source: Authors.

On the basis of the eight treatments and the six repetitions, the average weights of the quails in each of the three lines (lines 1 to 3) were calculated for each 7-day time interval.

We used the following nonlinear logistic model for the estimation of growth curve parameters:

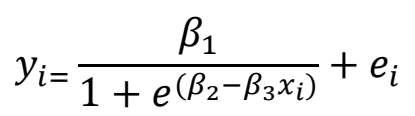

Where $\mathrm{y}_{\mathrm{i}}$ is the body weight at age $\mathrm{x}_{\mathrm{i}} ; \beta_{1}$ is the asymptotic weight when $t$ tends to infinity (this parameter is interpreted as weight at adulthood or weight at maturity); $\beta_{2}$ is a constant of integration, related to the initial weights of the animal and without defined biological interpretation, the value of which is established by the initial values of $y$ and $x$; and $\beta_{3}$ is interpreted as the maturation rate or growth speed, which represents the change in weight in relation to the weight at maturity, and is used as an indicator of the speed with which the animal approaches its adult size.

The identity method of nonlinear regression models proposed by Regazzi (2003) and Regazzi and Silva (2010) was applied in order to verify differences in parameter estimates between treatments analyzed for each strain and between lines analyzed for each treatment.

To employ this method, we used a logistic model plus a dummy variable (Puiatti et al., 2020; Safari and Erfani, 2020) to represent each of the eight treatments for each of the three lines. This model, which we refer to as the complete model, is as follows: 


$$
\mathrm{y}_{\mathrm{ik}}=\sum_{\mathrm{k}=1}^{\mathrm{K}} \mathrm{D}_{\mathrm{k}}\left[\frac{\beta_{1 \mathrm{k}}}{\left(1+\mathrm{e}^{\left(\beta_{2 \mathrm{k}}-\beta_{3 \mathrm{k}} \mathrm{x}_{\mathrm{i}}\right)}\right)}\right]+\mathrm{e}_{\mathrm{i}}
$$

Where $\mathrm{K}$ : varies from 1 to 8 for the treatments for each strain, and from 1 to 3 for the lines in each treatment;

$$
\begin{aligned}
& D_{k} \text { is an indicator variable, such that: } D_{k} \\
& \qquad=\left\{\begin{array}{l}
1 \text { if the observation } y_{i k} \text { belongs to the k group } \\
0 \text { otherwise }
\end{array}\right.
\end{aligned}
$$

And $\beta_{1 \mathrm{k}}, \beta_{2 \mathrm{k}}$, and $\beta 3_{\mathrm{k}}$ are the parameters of the model; and $\mathrm{e}_{\mathrm{i}}$ is the random error term, $\mathrm{e}_{\mathrm{i}}$ $\sim \mathrm{N}\left(0, \sigma^{2}\right)$.

Adjustment of the complete model (equation 2) is necessary to use the likelihood ratio method (Regazzi, 2003; Regazzi and Silva, 2010), which enables testing of the hypotheses for the eight treatments for each strain $(K=8)$ and the three lines in each treatment $(K=3)$ :

$\mathrm{H}_{0}: \beta_{11=} \beta_{12=\ldots}=\beta_{1 \mathrm{k}}$ vs $\mathrm{H}_{1}$ : not all $\beta_{1 \mathrm{k}}$ values are the same

$\mathrm{H}_{0}: \beta_{21}=\beta_{22=\ldots}=\beta_{2 \mathrm{k}}$ vs $\mathrm{H}_{1}$ : not all $\beta_{2 \mathrm{k}}$ values are the same

$\mathrm{H}_{0}: \beta_{31}=\beta_{32=\ldots}=\beta_{3 \mathrm{k}}$ vs $\mathrm{H}_{1}$ : not all $\beta_{3 \mathrm{k}}$ values are the same

For all parameters, comparisons were made using the $\mathrm{H}_{0}$ hypothesis test. This required the use of the complete model for the treatment $(\mathrm{k}=8)$ and strain $(\mathrm{k}=3)$ groups:

$$
\mathrm{y}_{\mathrm{i}}=\mathrm{D}_{1} \frac{\beta_{11}}{\left(1+\mathrm{e}^{\left(\beta_{21}-\beta_{31} \mathrm{x}_{\mathrm{i}}\right)}\right)}+\mathrm{D}_{2} \frac{\beta_{12}}{\left(1+\mathrm{e}^{\left(\beta_{22}-\beta_{32} \mathrm{x}_{\mathrm{i}}\right)}\right)}+\cdots+\mathrm{D}_{\mathrm{k}} \frac{\beta_{1 \mathrm{k}}}{\left(1+\mathrm{e}^{\left(\beta_{2 \mathrm{k}}-\beta_{3 \mathrm{k}} \mathrm{x}_{\mathrm{i}}\right)}\right)}+\mathrm{e}_{\mathrm{i}}
$$

Comparisons also required a reduced model for each parameter $\beta_{\mathrm{j}}$, where $\mathrm{j}=1,2$, or 3 , for the treatment $(\mathrm{k}=8)$ and lines groups $(\mathrm{k}=3)$ groups:

$$
\mathrm{y}_{\mathrm{i}}=\mathrm{D}_{1} \frac{\beta_{1}}{\left(1+\mathrm{e}^{\left(\beta_{21}-\beta_{31} \mathrm{x}_{\mathrm{i}}\right)}\right)}+\mathrm{D}_{2} \frac{\beta_{1}}{\left(1+\mathrm{e}^{\left(\beta_{22}-\beta_{32} \mathrm{x}_{\mathrm{i}}\right)}\right)}+\cdots+\mathrm{D}_{\mathrm{k}} \frac{\beta_{1}}{\left(1+\mathrm{e}^{\left(\beta_{2 \mathrm{k}}-\beta_{3 \mathrm{k}} \mathrm{x}_{\mathrm{i}}\right)}\right)}+\mathrm{e}_{\mathrm{i}}
$$

Similar complete and reduced models were constructed for the other two parameters $\beta_{2}$ and $\beta_{3}$. 
The sum of squares of the waste from the complete and reduced model adjustments, represented respectively by $\operatorname{RSS}_{\Omega}$ and $\mathrm{RSS} \omega$, were used to obtain the following chi-square statistic: $\chi_{\text {calculated }}^{2}=\mathrm{N} \ln \left(\mathrm{RSS}_{\Omega} / \mathrm{RSS} \omega\right)$. The decision rule is to reject $\mathrm{H}_{0}$ at a level of significance $\alpha$ if $\chi^{2}$ calculated $\geq \chi^{2 \alpha(v)}$, where $\nu=p_{\Omega}-p_{\omega}$ is the number of degrees of freedom, and $\mathrm{p}_{\Omega}$ and $\mathrm{p}_{\omega} \mathrm{O}$ are the number of parameters estimated in the complete and reduced models, respectively.

Details of the application of the likelihood ratio test, with approximation using chisquare statistics, have been described by Regazzi and Silva (2010). Model identity has been applied in plant and animal development studies, in order to verify the possibility of adjusting common equations for different groups of individuals (Santos et al., 2012).

On the basis of a comparison of the two approximations, i.e., $\chi^{2}$ and $F$ statistics obtained by data simulation, Regazzi and Silva (2010) concluded that for a sufficiently large total number of observations $(N \geq 120)$, the two approximations are almost equivalent, and that for smaller samples, it is preferential to use the approximation given by the F statistic, as the type I error rate is invariably lower, regardless of the value of $N$.

Rejection of the $\mathrm{H}_{0}$ hypothesis indicates that there is at least a difference between the estimates of the parameter $\beta_{\mathrm{j}}$, and in this event a new set of hypotheses is proposed in order to identify which strain in each treatment group $(\mathrm{k}=1,2,3)$ is equal to or different from the parameter $\beta_{1}$ :

$\mathrm{H}_{0}: \beta_{11}=\beta_{12}$ vs $\mathrm{H}_{1}: \beta_{1 \mathrm{k}}$ values are statistically different

$H_{0}: \beta_{11}=\beta_{13}$ vs $H_{1}: \beta_{1 \mathrm{k}}$ values are statistically different

$\mathrm{H}_{0}: \beta_{12}=\beta_{13} \mathrm{vs}_{1}: \beta_{1 \mathrm{k}}$ values are statistically different

For this purpose, we used formulae 5 and 6 for the complete and reduced models respectively, which are illustrated for a comparison between lines 1 and 2 as follows:

$$
\begin{aligned}
& y_{i}=D_{1} \frac{\beta_{11}}{\left(1+e^{\left(\beta_{21}-\beta_{31} x_{i}\right)}\right)}+D_{2} \frac{\beta_{12}}{\left(1+e^{\left(\beta_{22}-\beta_{32} x_{i}\right)}\right)}+e_{i} \\
& y_{i}=D_{1} \frac{\beta_{1}}{\left(1+e^{\left(\beta_{21}-\beta_{31} x_{i}\right)}\right)}+D_{2} \frac{\beta_{1}}{\left(1+e^{\left(\beta_{22}-\beta_{32} x_{i}\right)}\right)}+e_{i}
\end{aligned}
$$

The logistic model was adjusted to the quail weight-age data for treatments for each strain and the lines in each treatment based on the Gauss-Newton method using PROC MODEL in SAS (Statistical Analysis System, version 9.0, 2002) with the aid of dummy variables. 


\section{Results and Discussions}

Using the average weights obtained for each strain in response to the eight treatments (Table 2), we performed equality tests for the parameters of the logistic model (Table 3), and noted that for all treatments, there were no significant differences among the three lines with respect to adult weight $\left(\beta_{1}\right)$, the integration constant $\left(\beta_{2}\right)$ of the model, or the maturation rate $\left(\beta_{3}\right)$, and therefore the estimates for each parameter were considered equal (Table 4).

Table 2 - Average weights ${ }^{1}$ obtained by treatment in lines.

\begin{tabular}{|c|c|c|c|c|c|c|c|c|c|}
\hline \multirow{2}{*}{\multicolumn{2}{|c|}{ Age (days) }} & \multicolumn{8}{|c|}{ Treatments } \\
\hline & & $\mathrm{T} 1$ & $\mathrm{~T} 2$ & T3 & $\mathrm{T} 4$ & T5 & T6 & $\mathrm{T} 7$ & T8 \\
\hline \multirow{6}{*}{$\overline{\mathscr{e}}$} & 7 & 23.83 & 23.23 & 24.00 & 23.90 & 24.23 & 23.58 & 23.75 & 23.21 \\
\hline & 14 & 63.09 & 68.45 & 73.81 & 73.36 & 65.18 & 68.16 & 68.75 & 71.49 \\
\hline & 21 & 113.20 & 124.17 & 132.40 & 129.46 & 120.93 & 125.56 & 127.18 & 129.39 \\
\hline & 28 & 165.09 & 175.73 & 187.27 & 182.88 & 176.33 & 179.36 & 178.29 & 182.68 \\
\hline & 35 & 206.52 & 219.62 & 227.15 & 222.99 & 218.01 & 223.23 & 218.71 & 220.12 \\
\hline & 42 & 257.32 & 263.14 & 264.95 & 261.20 & 257.13 & 263.45 & 257.22 & 259.63 \\
\hline \multirow{6}{*}{ 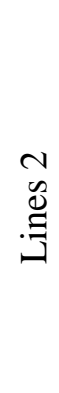 } & 7 & 26.22 & 28.69 & 27.30 & 27.31 & 27.28 & 26.51 & 26.52 & 28.24 \\
\hline & 14 & 62.73 & 69.40 & 70.00 & 70.60 & 64.12 & 64.91 & 69.12 & 73.10 \\
\hline & 21 & 115.69 & 127.50 & 128.15 & 131.39 & 116.30 & 126.72 & 127.32 & 132.87 \\
\hline & 28 & 167.18 & 184.12 & 180.37 & 186.16 & 166.29 & 179.23 & 183.70 & 187.87 \\
\hline & 35 & 199.17 & 211.06 & 212.41 & 209.95 & 202.22 & 216.85 & 221.57 & 231.48 \\
\hline & 42 & 227.37 & 240.69 & 238.09 & 249.99 & 236.75 & 246.81 & 251.43 & 253.77 \\
\hline \multirow{6}{*}{$\stackrel{m}{\mathscr{0}}$} & 7 & 25.50 & 25.33 & 25.68 & 25.14 & 26.14 & 25.14 & 24.90 & 26.27 \\
\hline & 14 & 62.35 & 66.00 & 67.57 & 71.13 & 60.33 & 65.34 & 67.59 & 65.35 \\
\hline & 21 & 113.22 & 123.38 & 125.74 & 127.29 & 115.17 & 121.42 & 126.81 & 124.48 \\
\hline & 28 & 160.92 & 172.51 & 174.54 & 175.35 & 167.26 & 173.25 & 180.24 & 175.28 \\
\hline & 35 & 207.72 & 219.12 & 214.70 & 214.86 & 218.95 & 215.75 & 223.09 & 219.98 \\
\hline & 42 & 220.58 & 232.75 & 231.11 & 225.13 & 228.55 & 230.14 & 236.10 & 232.52 \\
\hline
\end{tabular}

${ }^{1}$ Standard error $=2.6827$. Source: Authors. 
Table 3 - Logistic model identity test for treatments within each lines.

\begin{tabular}{|c|c|c|c|c|c|}
\hline Lines & Hypotheses & $\mathrm{N}$ & $\mathrm{RSS}_{\Omega}$ & $\mathrm{RSS}_{\varphi}$ & $\chi_{\text {calculated }}^{2}$ \\
\hline \multirow{3}{*}{ Lines 1} & $\mathrm{H} 0: \beta_{11}=\beta_{12}=\ldots=\beta_{18} \mathrm{vs} \mathrm{H}_{1} *$ & 48 & 580.2 & 648.3 & 5.3271 \\
\hline & $\mathrm{H} 0: \beta_{21}=\beta_{22}=\ldots=\beta_{28}$ vs $\mathrm{H}_{1}$ & 48 & 580.2 & 601.4 & 1.7226 \\
\hline & $\mathrm{H} 0: \beta_{31}=\beta_{32}=\ldots=\beta_{38}$ vs $\mathrm{H}_{1}$ & 48 & 580.2 & 641.9 & 4.8509 \\
\hline \multirow{3}{*}{ Lines 2} & $\mathrm{H} 0: \beta_{11}=\beta_{12}=\ldots=\beta_{18} \mathrm{vs} \mathrm{H}_{1}$ & 48 & 1003.4 & 1138.4 & 6.0590 \\
\hline & H0: $\beta_{21}=\beta_{22}=\ldots=\beta_{28}$ vs $\mathrm{H}_{1}$ & 48 & 1003.4 & 1035.5 & 1.5115 \\
\hline & $\mathrm{H} 0: \beta_{31}=\beta_{32}=\ldots=\beta_{38} \mathrm{vs} \mathrm{H}_{1}$ & 48 & 1003.4 & 1043.2 & 1.8671 \\
\hline \multirow{3}{*}{ Lines 3} & $\mathrm{H} 0: \beta_{11}=\beta_{12}=\ldots=\beta_{18}$ vs H$_{1}$ & 48 & 1010.3 & 1055.3 & 2.0917 \\
\hline & $\mathrm{H} 0: \beta_{21}=\beta_{22}=\ldots=\beta_{28}$ vs $\mathrm{H}_{1}$ & 48 & 1010.3 & 1043.5 & 1.5520 \\
\hline & $\mathrm{H} 0: \beta_{31}=\beta_{32}=\ldots=\beta_{38}$ vs $\mathrm{H}_{1}$ & 48 & 1010.3 & 1028.6 & 0.8617 \\
\hline
\end{tabular}

$\mathrm{RSS}_{\Omega}$ - residual sum of squares full model; $\mathrm{RSS}_{\varphi}$ - residual sum of squares reduced models; $* \mathrm{H}_{1}$ - indicates that there is at least one difference between diets in relation to each of the curve parameters within each studied lines; $\beta_{\mathrm{ij}}$ where: $\mathrm{i}=$ parameter; $\mathrm{j}=$ treatments; $\mathrm{N}-8$ treatments $\times 6$ time intervals $=48 ; v-24-17=7 ; X^{2}$ tabulated $5 \%(7)=14.06714$. Source: Authors. 
(CC BY 4.0) | ISSN 2525-3409 | DOI: http://dx.doi.org/10.33448/rsd-v9i10.9328

Table 4 - Estimates of the parameters for treatments within each lines.

\begin{tabular}{|c|c|c|c|c|}
\hline Lines & Treatments & $\widehat{\beta}_{1}$ & $\widehat{\beta}_{2}$ & $\widehat{\beta}_{3}$ \\
\hline \multirow{8}{*}{1} & 1 & $318.84 \pm 21.65$ & $14.18 \pm 1.57$ & $0.0955 \pm 0.0082$ \\
\hline & 2 & $305.95 \pm 15.50$ & $13.76 \pm 1.67$ & $0.1037 \pm 0.0082$ \\
\hline & 3 & $294.39 \pm 11.82$ & $13.31 \pm 1.73$ & $0.1114 \pm 0.0084$ \\
\hline & 4 & $293.36 \pm 12.62$ & $12.95 \pm 1.65$ & $0.1086 \pm 0.0084$ \\
\hline & 5 & $293.28 \pm 13.60$ & $14.64 \pm 1.95$ & $0.1091 \pm 0.0086$ \\
\hline & 6 & $300.62 \pm 13.74$ & $14.26 \pm 1.83$ & $0.1082 \pm 0.0084$ \\
\hline & 7 & $289.26 \pm 12.76$ & $13.50 \pm 1.77$ & $0.1092 \pm 0.0086$ \\
\hline & 8 & $288.64 \pm 12.08$ & $13.28 \pm 1.75$ & $0.1106 \pm 0.0086$ \\
\hline \multirow{8}{*}{2} & 1 & $251.51 \pm 14.35$ & $13.05 \pm 2.63$ & $0.1137 \pm 0.0130$ \\
\hline & 2 & $260.37 \pm 12.53$ & $12.58 \pm 2.46$ & $0.1179 \pm 0.0125$ \\
\hline & 3 & $258.13 \pm 12.40$ & $12.55 \pm 2.48$ & $0.1183 \pm 0.0127$ \\
\hline & 4 & $270.17 \pm 13.67$ & $12.15 \pm 2.23$ & $0.1138 \pm 0.0120$ \\
\hline & 5 & $271.93 \pm 18.39$ & $12.37 \pm 2.15$ & $0.1042 \pm 0.0119$ \\
\hline & 6 & $270.97 \pm 13.73$ & $14.17 \pm 2.76$ & $0.1174 \pm 0.0123$ \\
\hline & 7 & $277.13 \pm 13.94$ & $13.79 \pm 2.59$ & $0.1161 \pm 0.0119$ \\
\hline & 8 & $279.81 \pm 13.14$ & $13.29 \pm 2.46$ & $0.1175 \pm 0.0118$ \\
\hline \multirow{8}{*}{3} & 1 & $247.13 \pm 13.58$ & $14.10 \pm 3.02$ & $0.1178 \pm 0.0135$ \\
\hline & 2 & $256.06 \pm 12.23$ & $14.51 \pm 3.09$ & $0.1226 \pm 0.0132$ \\
\hline & 3 & $251.40 \pm 11.73$ & $13.65 \pm 2.91$ & $0.1228 \pm 0.0133$ \\
\hline & 4 & $243.35 \pm 10.60$ & $13.15 \pm 2.90$ & $0.1264 \pm 0.0138$ \\
\hline & 5 & $254.68 \pm 12.62$ & $16.41 \pm 3.67$ & $0.1244 \pm 0.0135$ \\
\hline & 6 & $251.63 \pm 11.80$ & $14.81 \pm 3.25$ & $0.1246 \pm 0.0135$ \\
\hline & 7 & $255.93 \pm 10.99$ & $15.25 \pm 3.37$ & $0.1285 \pm 0.0134$ \\
\hline & 8 & $254.24 \pm 11.59$ & $14.88 \pm 3.25$ & $0.1255 \pm 0.0134$ \\
\hline
\end{tabular}

Source: Authors.

The growth curves obtained from the estimates in the complete model (Table 4) analyzed graphically for the treatments for lines 1 to 3 are presented in Figure 1A to $1 \mathrm{C}$, respectively. Similarly, the model identity test was carried out using $\chi^{2}$ statistics $(N=144)$ for the lines within each treatment (Table 5) and, based on the tests performed, we concluded that with the exception of Treatment 5, for each treatment studied, the lines showed differences only 
Research, Society and Development, v. 9, n. 10, e9439109328, 2020

(CC BY 4.0) | ISSN 2525-3409 | DOI: http://dx.doi.org/10.33448/rsd-v9i10.9328

in terms of adult weight $\left(\beta_{1}\right)$. In contrast, responses to Treatment $5\left(3100 \mathrm{kcal} \mathrm{of} \mathrm{ME} \mathrm{kg}^{-1}\right.$ feed and $22 \% \mathrm{RP}$ ) showed no significant differences. We subsequently performed the model identity test in order to compare the adult weight parameter $\left(\beta_{1}\right)$ of the lines within each treatment (Table 6), which, with the exception of Treatment 5, did not indicate a significant difference.

Table 5 - Logistic model identity test for lines within each treatments.

\begin{tabular}{|c|c|c|c|c|c|}
\hline Treatments & Hypotheses & $\mathrm{N}$ & $\operatorname{RSS}_{\Omega}$ & $\mathrm{RSS}_{\varphi}$ & $\chi_{\text {calculated }}^{2}$ \\
\hline \multirow{3}{*}{$\mathrm{T} 1$} & H0: $\beta_{11}=\beta_{12}=\ldots=\beta_{13}$ vs $\mathrm{H}_{1}$ & 18 & 330.4 & 701.5 & $13.5525 *$ \\
\hline & $\mathrm{H} 0: \beta_{21}=\beta_{22}=\ldots=\beta_{23} \mathrm{vs} \mathrm{H}_{1}$ & 18 & 330.4 & 337.6 & 0.3880 \\
\hline & $\mathrm{H} 0: \beta_{31}=\beta_{32}=\ldots=\beta_{33}$ vs $\mathrm{H}_{1}$ & 18 & 330.4 & 413.8 & 4.0514 \\
\hline \multirow{3}{*}{$\mathrm{T} 2$} & $\mathrm{H} 0: \beta_{11}=\beta_{12}=\ldots=\beta_{13} \mathrm{vs} \mathrm{H}_{1}$ & 18 & 359.8 & 629.8 & $10.0773 *$ \\
\hline & $\mathrm{H} 0: \beta_{21}=\beta_{22}=\ldots=\beta_{23}$ vs $\mathrm{H}_{1}$ & 18 & 359.8 & 370.0 & 0.5031 \\
\hline & $\mathrm{H} 0: \beta_{31}=\beta_{32}=\ldots=\beta_{33}$ vs $\mathrm{H}_{1}$ & 18 & 359.8 & 418.4 & 2.7160 \\
\hline \multirow{3}{*}{$\mathrm{T} 3$} & $\mathrm{H} 0: \beta_{11}=\beta_{12}=\ldots=\beta_{13}$ vs $\mathrm{H}_{1}$ & 18 & 243.4 & 497.6 & $12.8716^{*}$ \\
\hline & $\mathrm{H} 0: \beta_{21}=\beta_{22}=\ldots=\beta_{23}$ vs $\mathrm{H}_{1}$ & 18 & 243.4 & 246.7 & 0.2424 \\
\hline & $\mathrm{H} 0: \beta_{31}=\beta_{32}=\ldots=\beta_{33}$ vs $\mathrm{H}_{1}$ & 18 & 243.4 & 262.1 & 1.3323 \\
\hline \multirow{3}{*}{$\mathrm{T} 4$} & $\mathrm{H} 0: \beta_{11}=\beta_{12}=\ldots=\beta_{13}$ vs $\mathrm{H}_{1}$ & 18 & 391.4 & 683.4 & $10.0323 *$ \\
\hline & $\mathrm{H} 0: \beta_{21}=\beta_{22}=\ldots=\beta_{23} \mathrm{vs} \mathrm{H}_{1}$ & 18 & 391.4 & 396.1 & 0.2148 \\
\hline & $\mathrm{H} 0: \beta_{11}=\beta_{12}=\ldots=\beta_{13} \mathrm{vs} \mathrm{H}_{1}$ & 18 & 391.4 & 435.4 & 1.9176 \\
\hline \multirow{3}{*}{$\mathrm{T} 5$} & $\mathrm{H} 0: \beta_{21}=\beta_{22}=\ldots=\beta_{23} \mathrm{vs} \mathrm{H}_{1}$ & 18 & 395.9 & 538.4 & 5.5339 \\
\hline & $\mathrm{H} 0: \beta_{31}=\beta_{32}=\ldots=\beta_{33}$ vs $\mathrm{H}_{1}$ & 18 & 395.9 & 439.6 & 1.8846 \\
\hline & $\mathrm{H} 0: \beta_{31}=\beta_{32}=\ldots=\beta_{33}$ vs $\mathrm{H}_{1}$ & 18 & 395.9 & 454.4 & 2.4806 \\
\hline \multirow{3}{*}{ T6 } & $\mathrm{H} 0: \beta_{21}=\beta_{22}=\ldots=\beta_{23} \mathrm{vs} \mathrm{H}_{1}$ & 18 & 293.5 & 533.4 & $10.7530 *$ \\
\hline & $\mathrm{H} 0: \beta_{31}=\beta_{32}=\ldots=\beta_{33}$ vs $\mathrm{H}_{1}$ & 18 & 293.5 & 294.6 & 0.0673 \\
\hline & $\mathrm{H} 0: \beta_{31}=\beta_{32}=\ldots=\beta_{33}$ vs $\mathrm{H}_{1}$ & 18 & 293.5 & 332.1 & 2.2240 \\
\hline \multirow{3}{*}{$\mathrm{T} 7$} & $\mathrm{H} 0: \beta_{21}=\beta_{22}=\ldots=\beta_{23} \mathrm{vs} \mathrm{H}_{1}$ & 18 & 267.4 & 403.6 & $7.4102 *$ \\
\hline & $\mathrm{H} 0: \beta_{31}=\beta_{32}=\ldots=\beta_{33}$ vs $\mathrm{H}_{1}$ & 18 & 267.4 & 277.9 & 0.6932 \\
\hline & $\mathrm{H} 0: \beta_{31}=\beta_{32}=\ldots=\beta_{33}$ vs $\mathrm{H}_{1}$ & 18 & 267.4 & 321.2 & 3.2997 \\
\hline \multirow{3}{*}{$\mathrm{T} 8$} & $\mathrm{H} 0: \beta_{21}=\beta_{22}=\ldots=\beta_{23}$ vs $\mathrm{H}_{1}$ & 18 & 311.7 & 456.8 & $6.8796^{*}$ \\
\hline & $\mathrm{H} 0: \beta_{31}=\beta_{32}=\ldots=\beta_{33}$ vs $\mathrm{H}_{1}$ & 18 & 311.7 & 320.8 & 0.5179 \\
\hline & $\mathrm{H} 0: \beta_{31}=\beta_{32}=\ldots=\beta_{33}$ vs $\mathrm{H}_{1}$ & 18 & 311.7 & 343.3 & 1.7381 \\
\hline
\end{tabular}

$\mathrm{RSS}_{\Omega}$ - residual sum of squares full model; $\mathrm{RSS}_{\omega}$ - residual sum of squares reduced models; ${ }^{*} \mathrm{H}_{1^{-}}$ indicates that there is at least one difference between in lines relation to each of the curve parameters within each studied diets; $\beta_{\mathrm{ij}}$ where: $\mathrm{i}=$ parameter; $\mathrm{j}=$ lines; $\mathrm{N}=3$ lines $\mathrm{x} 6$ time intervals $=18 ; v=9-$ $7=2 ; X^{2}$ tabulated $-5 \%(2)=5.99$. Source: Authors. 
Research, Society and Development, v. 9, n. 10, e9439109328, 2020

(CC BY 4.0) | ISSN 2525-3409 | DOI: http://dx.doi.org/10.33448/rsd-v9i10.9328

Table 6 - Logistic model identity test about adult weight parameter for lines within each treatments.

\begin{tabular}{ccccc}
\hline Hypotheses & $\mathrm{N}$ & $\mathrm{RSS}_{\Omega}$ & $\mathrm{RSS}_{\omega}$ & $\chi^{2}$ calculated \\
\hline Treatment 1 & 12 & 199.5 & 419.5 & $8.91^{*}$ \\
\hline $\mathrm{H} 0: \beta_{11}=\beta_{11}$ vs H$_{1}{ }^{*}$ & 12 & 228.1 & 513.0 & 9.72 \\
$\mathrm{H} 0: \beta_{11}=\beta_{12}$ vs H$_{1}$ & 12 & 236.1 & 238.5 & 0.12 \\
$\mathrm{H} 0: \beta_{11}=\beta_{13}$ vs H$_{1}$ & &
\end{tabular}

Treatment 2

$\begin{array}{lllll}\text { H0: } \beta_{11}=\beta_{11} \text { vs H} & 12 & 240.4 & 404.2 & 6.23^{*} \\ \text { H0: } \beta_{11}=\beta_{12} \text { vs H } & 12 & 189.4 & 402.7 & 9.05^{*} \\ \text { H0: } \beta_{11}=\beta_{13} \text { vs H } & 12 & 290.9 & 293.7 & 0.11\end{array}$

Treatment 3

$\begin{array}{llllc}\text { H0: } \beta_{11}=\beta_{11} \text { vs } \text { H}_{1} & 12 & 159.7 & 289.5 & 7.36^{*} \\ \text { H0: } \beta_{11}=\beta_{12} \text { vs } H_{1} & 12 & 148.0 & 349.3 & 10.30^{*} \\ \text { H0: } \beta_{11}=\beta_{13} \text { vs } \text { H}_{1} & 12 & 182.1 & 188.8 & 0.43\end{array}$

Treatment 4

$\begin{array}{llllc}\mathrm{H} 0: \beta_{11}=\beta_{11} \text { vs H}_{1} & 12 & 307.9 & 352.9 & 1.63 \\ \mathrm{H} 0: \beta_{11}=\beta_{12} \text { vs H} & 12 & 135.7 & 428.0 & 13.78^{*} \\ \mathrm{H} 0: \beta_{11}=\beta_{13} \text { vs H} & 12 & 339.7 & 441.9 & 3.15\end{array}$

\section{Treatment 6}

$\begin{array}{llllc}\text { H0: } \beta_{11}=\beta_{11} \text { vs H} & 12 & 191.0 & 263.5 & 3.86^{*} \\ \text { H0: } \beta_{11}=\beta_{12} \text { vs H} & 12 & 164.8 & 396.8 & 10.54^{*} \\ \text { H0: } \beta_{11}=\beta_{13} \text { vs H } & 12 & 231.4 & 278.8 & 2.23\end{array}$

Treatment 7

$\begin{array}{lllll}\text { H0: } \beta_{11}=\beta_{11} \text { vs H} & 12 & 161.3 & 175.2 & 0.99 \\ \text { H0: } \beta_{11}=\beta_{12} \text { vs H } & 12 & 186.9 & 318.4 & 6.39 * \\ \text { H0: } \beta_{11}=\beta_{13} \text { vs H } & 12 & 186.5 & 249.1 & 3.47\end{array}$

Treatment 8

$\begin{array}{lllll}\text { H0: } \beta_{11}=\beta_{11} \text { vs } \mathrm{H}_{1} & 12 & 164.1 & 173.6 & 0.67 \\ \mathrm{H} 0: \beta_{11}=\beta_{12} \text { vs H} & 12 & 234.0 & 371.1 & 5.53 \\ \mathrm{H} 0: \beta_{11}=\beta_{13} \text { vs H} & 12 & 225.1 & 313.4 & 3.97\end{array}$

$\mathrm{RSS}_{\Omega}$ - residual sum of squares full model; $\mathrm{RSS}_{\omega}$ - residual sum of squares reduced models; $* \mathrm{H}_{1}$ - indicates that there is at least one difference between in lines relation the parameter $\beta_{1}$ of the curve. within each studied diet; $\mathrm{N}=$ 2 lines x 6 time intervals $=12 ; v=6-5=1 ; X^{2}$ tabulated $-5 \%(1)=3.84$. Source: Authors. 
Figure 1 - Estimated growth curves, adjusted by the Logistic model, for Treatments in Line 1 (A), Line 2 (B) and Line 3 (C).

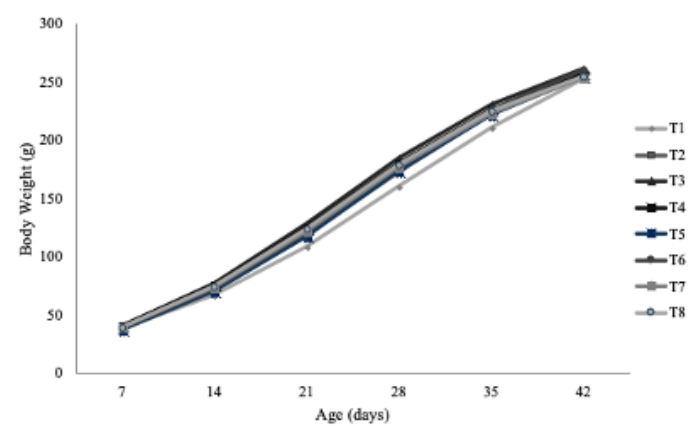

(A)

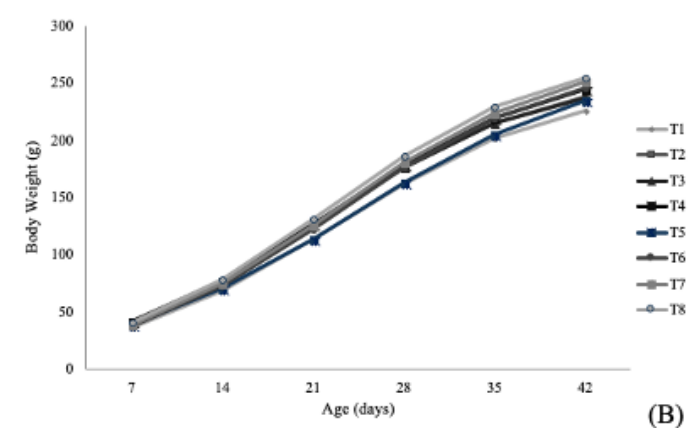

(B)

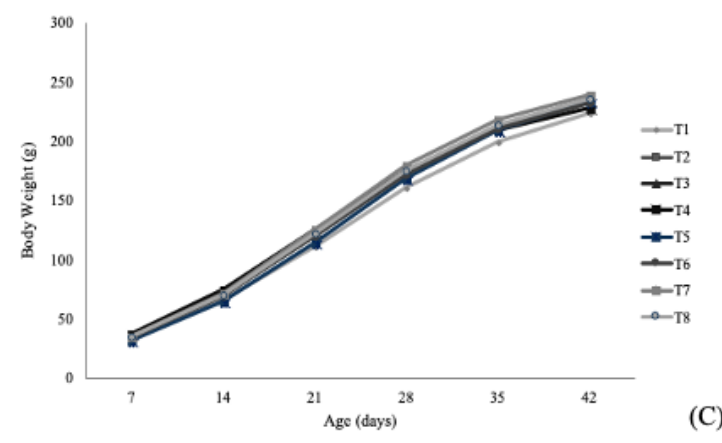

Source: Authors.

Growth curves obtained on the basis of estimates using the complete model (Table 7) are presented graphically for treatments $1,2,3,4,6,7$, and 8 in figures $2 \mathrm{~A}, 2 \mathrm{~B}, 2 \mathrm{C}, 2 \mathrm{D}, 3 \mathrm{~A}$, $3 \mathrm{~B}$ and $3 \mathrm{C}$, respectively. Estimates of the adult weight parameter $\left(\widehat{\beta}_{1}\right)$ for each strain in response to the different treatments indicated that Line 1 had a higher adult weight when compared with the other two lines (Table 7). With the exception of Treatment 5, we detected a strong inverse relationship between adult weight $\left(\widehat{\beta}_{1}\right)$ and the maturation rate $\left(\widehat{\beta}_{3}\right)$ in response to all other treatments, and therefore it can be inferred that the different nutritional treatments had no significant effect on the growth curve of European quails. 
Research, Society and Development, v. 9, n. 10, e9439109328, 2020

(CC BY 4.0) | ISSN 2525-3409 | DOI: http://dx.doi.org/10.33448/rsd-v9i10.9328

Table 7 - Estimates of the parameters for lines within each treatments.

\begin{tabular}{|c|c|c|c|c|}
\hline Treatments & Lines & $\widehat{\beta}_{1}$ & $\widehat{\beta}_{2}$ & $\widehat{\beta}_{3}$ \\
\hline \multirow{3}{*}{1} & 1 & $320.54 \pm 26.90$ & $14.18 \pm 1.92$ & $0.0953 \pm 0.0101$ \\
\hline & 2 & $251.59 \pm 13.47$ & $13.05 \pm 2.46$ & $0.1137 \pm 0.0122$ \\
\hline & 3 & $247.13 \pm 12.68$ & $14.10 \pm 2.82$ & $0.1178 \pm 0.0126$ \\
\hline \multirow{3}{*}{2} & 1 & $307.26 \pm 20.15$ & $13.75 \pm 2.13$ & $0.1034 \pm 0.0106$ \\
\hline & 2 & $260.79 \pm 12.36$ & $12.47 \pm 2.37$ & $0.1174 \pm 0.0122$ \\
\hline & 3 & $255.97 \pm 11.89$ & $14.56 \pm 3.03$ & $0.1228 \pm 0.0129$ \\
\hline \multirow{3}{*}{3} & 1 & $294.39 \pm 12.50$ & $13.31 \pm 1.83$ & $0.1114 \pm 0.0089$ \\
\hline & 2 & $258.21 \pm 9.98$ & $12.53 \pm 1.99$ & $0.1182 \pm 0.0102$ \\
\hline & 3 & $251.70 \pm 9.46$ & $13.49 \pm 2.29$ & $0.1223 \pm 0.0106$ \\
\hline \multirow{3}{*}{4} & 1 & $293.71 \pm 16.97$ & $12.94 \pm 2.21$ & $0.1085 \pm 0.0113$ \\
\hline & 2 & $270.17 \pm 13.94$ & $12.15 \pm 2.27$ & $0.1138 \pm 0.0122$ \\
\hline & 3 & $243.34 \pm 10.77$ & $13.16 \pm 2.95$ & $0.1264 \pm 0.0140$ \\
\hline \multirow{3}{*}{6} & 1 & $300.62 \pm 15.95$ & $14.26 \pm 2.12$ & $0.1082 \pm 0.0097$ \\
\hline & 2 & $270.90 \pm 12.11$ & $14.19 \pm 2.44$ & $0.1174 \pm 0.0108$ \\
\hline & 3 & $251.78 \pm 10.42$ & $14.73 \pm 2.84$ & $0.1243 \pm 0.0119$ \\
\hline \multirow{3}{*}{7} & 1 & $289.26 \pm 14.14$ & $13.50 \pm 1.97$ & $0.1092 \pm 0.0095$ \\
\hline & 2 & $277.07 \pm 11.74$ & $13.80 \pm 2.19$ & $0.1162 \pm 0.0101$ \\
\hline & 3 & $255.72 \pm 9.19$ & $15.45 \pm 2.89$ & $0.1290 \pm 0.0113$ \\
\hline \multirow{3}{*}{8} & 1 & $288.64 \pm 14.46$ & $13.28 \pm 2.10$ & $0.1106 \pm 0.0103$ \\
\hline & 2 & $279.72 \pm 11.94$ & $13.32 \pm 2.25$ & $0.1176 \pm 0.0107$ \\
\hline & 3 & $254.14 \pm 10.49$ & $14.95 \pm 2.97$ & $0.1257 \pm 0.0122$ \\
\hline
\end{tabular}

Source: Authors. 
Figure 2 - Estimated growth curves, adjusted by the Logistic model, for Line in Treatment 1 (A), Treatment 2 (B), Treatment 3 (C) and Treatment 4 (D).

(A)

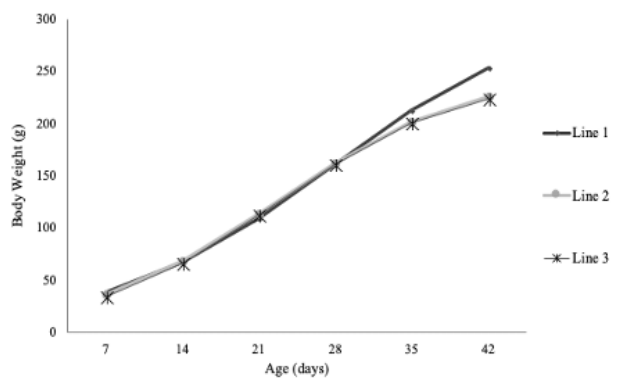

(C)

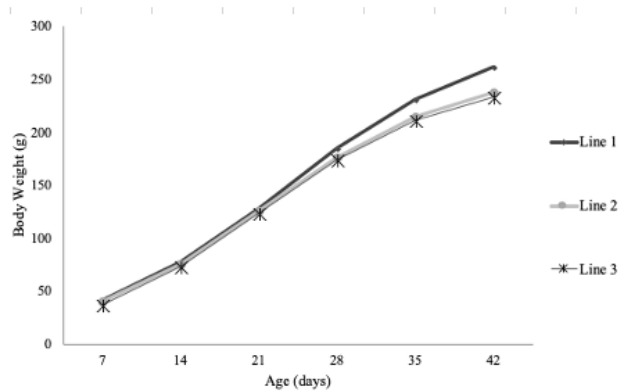

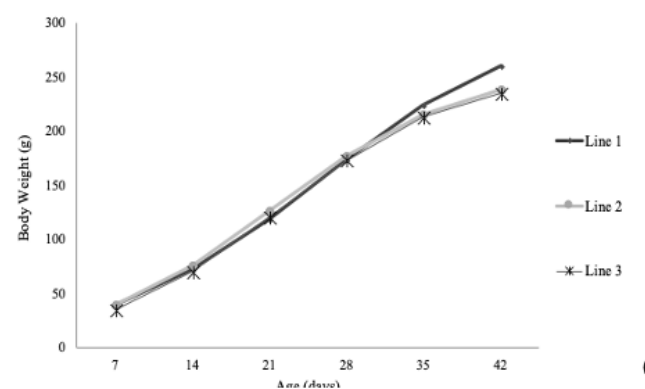

(B)

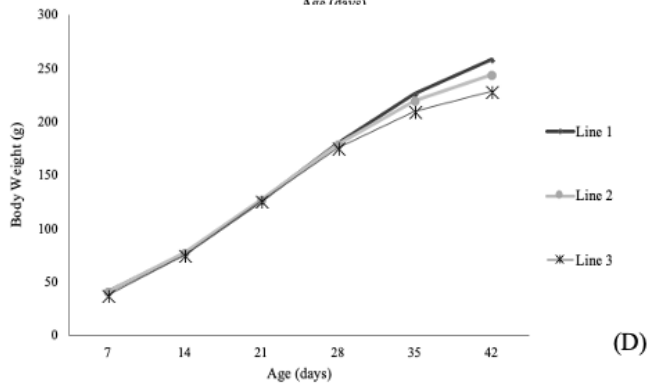

Source: Authors.

Figure 3 - Estimated growth curves, adjusted by the Logistic model, for Line in Treatment 6 (A), Treatment 7 (B) and Treatment 8 (C).
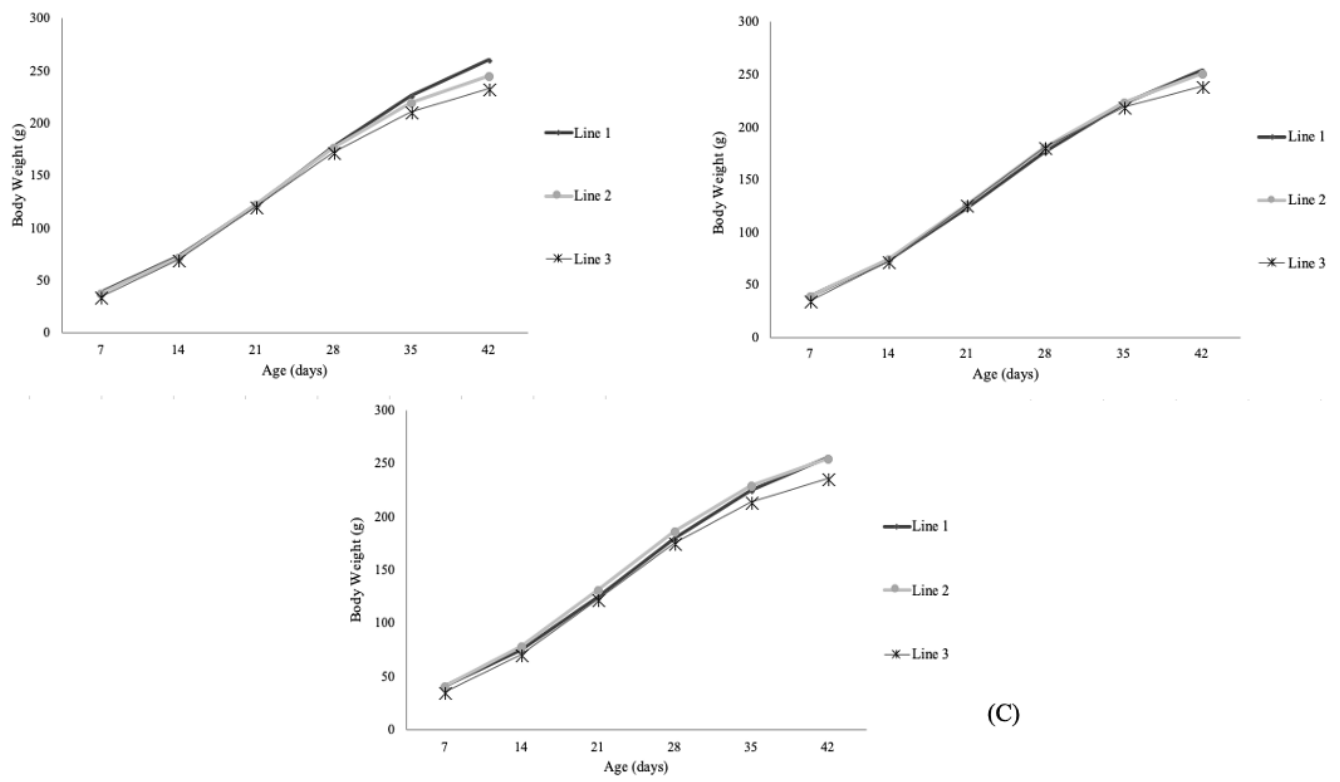

(C)

Source: Authors.

We observed a strong inverse relationship $(r=-0.94)$ between adult weight $\left(\widehat{\beta}_{1}\right)$ and maturation rate $\left(\widehat{\beta}_{3}\right)$ only in Strain 1, which was expected, given that the higher the adult weight, the lower is the rate of maturation (Grieser et al., 2015). Biologically, this correlation can be 
interpreted as indicating that animals with higher growth rates are less likely to reach higher weights at maturity than those that grow more slowly in early life; that is, birds that are heavier at maturity tend to have a lower growth rate (Karadavut et al., 2017). It should be noted that this relationship is biologically the most important (Kaplan and Gürcan, 2018).

These differences in adult weight highlight the fact that the lines examined in this study have been selected for slaughter weight. In contrast, weight gain does not appear to have been a focus of selection for these lines, as we detected no significant differences with respect to the maturation rate parameter. Previously, Santos et al. (2018) have shown that European quail lines specifically bred for meat production have a higher adult weight range than that of Japanese quail lines, whereas Sezer and Tarhan (2005) have observed distinct growth behavior in the first and second growth phases of three quail lines, which indicates that different sets of genes can determine differences in the early and late growth of lines. Additionally, a difference in the growth curve with respect later weights was considered to reflect a significant effect of the adult weight parameter for the different lines evaluated. However, the same authors failed to observe any significant difference in the growth rate, which is consistent with the findings of the present study.

Some authors have studied the effect of selection or the nutritional levels of diets (Zancanela et al., 2015; Santos et al., 2018) on the growth curves of quails, and have inferred that further studies should investigate the effects of diet on the quail growth curve. Furthermore, using standard and reaction models, Mota et al. (2015) examined the effects of genotype $\times$ environment interactions with respect to different diets on the body weight of quails, and accordingly observed that nutritional levels affected body weight only under less favorable environmental conditions.

Similar to the present study, Bonafé et al. (2011) evaluated the identity of nonlinear regression models to assess the growth of two broiler quail lines, adjusted Richards' nonlinear regression model to the data, and performed a parameter equality test, and accordingly deduced that two curves are necessary, as the parameters were significantly different for the two lines. Moreover, in a comparison of the growth of two generations of Japanese quails using the Gompertz model, Santos et al. (2018) performed a parameter equality test of the model and concluded that a common equation should not be used to describe the growth of the two generations. 


\section{Conclusion}

On the basis of the findings of this study, we can conclude that the use of a single curve is inappropriate for characterizing the growth of different quail lines, evaluated with respect to different nutritional management. We found that adult weight was the parameter that contributed to the observed differences found. The model identity technique is considered to represents a strategic approach that can be used to determine more efficient nutritional management and facilitate the design of selection programs for specific lines.

\section{Acknowledgements}

The Coordenação de Aperfeiçoamento de Pessoal de Nível Superior (CAPES), Brazil Finance Code 001, for the scholarship provided.

\section{References}

Arango, J. A., \& Van Vleck, L. D. (2002). Size of beef cows: early ideas, new developments. Genetics and Molecular Research, 1, 51-63.

Bonafé, C. M., Torres, R. A., Sarmento, J. L. R., Silva, L. P., Ribeiro, J. C., Teixeira, R. B., Silva, F. G. \& Sousa, M. F. (2011). Random regression models for description of growth curve of meat quails. Brazilian Journal of Animal Science, 40, 765-771.

Brusamarelo, E., da Silva Pereira, T. V., Brusamarelo, D., Souza, C. S., de Oliveira, H. C., Corrêa, G. S. S., Corrêa, A. B. \& de Oliveira, C. F. S. (2020). Modelo de crescimento de Gompertz na avicultura: algumas considerações. Research, Society and Development, 9(8), e508985208-e508985208.

Grieser, D. O., Marcato, S. M., Furlan, A. C., Zancanela, V., Ton, A. P. S., Batista, E., Perine, T. P., Pozza, P. C. \& Sakomura, N. C. (2015). Comparison of growth curve parameters of organs and body components in meat (Coturnix coturnix coturnix) and laying-type (Coturnix coturnix japonica) quail show interactions between gender and genotype. Journal of British Poultry Science, 56, 6-14. 
Kaplan, S. \& Gürcan, E. K. (2018). Comparison of growth curves using non-linear regression function in Japanese quail. Journal of Applied Animal Research, 46, 112-117.

Karadavut, U., Taskin, A. \& Genc, S. (2017). Comparison of growth curve models in Japanese quail raised in cages enriched with different colored lights. Brazilian Journal of Animal Science, 46, 839-846.

Mota, L. F. M., Abreu, L. R. A., Silva, M. A., Pires, A. V., Lima, H. J. D., Bonafé, C. M. \& Martins, P. G. M. A. (2015). Genotype $\times$ dietary (methionine+cystine): Lysine ratio interaction for body weight of meat-type quails using reaction norm models. Livestock Science, 182, 137144.

Puiatti, G. A., Cecon, P. A., Nascimento, M., Nascimento, A. C. A., Carneiro, A. P. S., Silva, F. F., Puiatti, M. \& Cruz, C. D. (2020). Nonlinear quantile regression to describe the dry matter accumulation of garlic plants. Ciência Rural 50: 1-e20180385.

Regazzi, A. J. (2003). Teste para verificar a igualdade de parâmetros e a identidade de modelos de regressão não-linear. Revista Ceres 50, 9-26.

Regazzi, A. J. \& Silva, C. H. O. (2010). Testes para verificar a igualdade de parâmetros e a identidade de modelos de regressão não-linear em dados de experimento com delineamento em blocos casualizados. Revista Ceres, 57, 315-320.

Safari, S. \& Erfani, A. R. (2020). A new method for fuzzification of nested dummy variables by fuzzy clustering membership functions and its application in financial economy. Iranian Journal of Fuzzy Systems, 17, 13-27.

Santos, T. C., Murakami, A. E., Oliveira, C. A. L. \& Costa, P. D. (2012). Body and testicular development in males of meat- and egg-type quails of 25 to 360 days. Pesquisa Veterinária Brasileira, 32, 1205-1212.

Santos, H. B., Vieira, D. A., Souza, L. P., Santos, A. L., Santos, F. R. \& Araújo Neto, F. R. (2018). Application of non-linear mixed models for modelling the quail growth curve for meat and laying. Journal of Agricultural Science, 156, 1216-1221. 
Sezer, M. \& Tarhan, S. (2005). Model parameters of growth curves of three meat type lines of Japanese quail. Czech Journal of Animal Science, 50, 22-30.

Silva, F. L., Alencar, M. M., Freitas, A. R., Packer, I. U. \& Mourão, G. B. (2011). Growth curves in beef cows of different biological types. Pesquisa Veterinária Brasileira, 46, 262-271.

Silveira, F. G., Silva, F. F., Carneiro, P. L. S., Malhado, C. H. M. \& Muniz, J. A. (2011). Cluster analysis applied to nonlinear regression models selection to growth curves of crossed lambs. Ciência Rural, 41, 692-698.

Souza, L. A., Caires, D. N., Carneiro, P. L. S., Malhado, C. H. M. \& Martins Filho, R. 2010. Growth rate curves of Indubrasil cattle raised at Sergipe State. Revista Ciência Agronômica, 41, 671-676.

Zancanela, V., Marcato, S. M., Furlan, A. C., Grieser, D. O., Ton, A. P. S., Batista, E. \& Pozza, P. C. (2015). Models for predicting energy requirements in meat quail. Livestock Science, 171, 12-19.

\section{Percentage of contribution of each author in the manuscript}

Marta Jeidjane Borges Ribeiro - 14.2\%

Fabyano Fonseca e Silva - 14.2\%

Claudson Oliveira Brito $-14.2 \%$

Ana Paula Del Vesco - $14.2 \%$

Maise Santos Macário - 14.2\%

Camilla Mendonça Silva $-14.2 \%$

Leandro Teixeira Barbosa - 14.2\% 